\title{
Erratum to: Guest editorial: Molecular mechanisms of lymphocyte development: recent findings
}

\author{
Takafumi Yokota
}

Published online: 13 September 2014

(c) The Japanese Society of Hematology 2014

Erratum to: Int J Hematol (2014) 100:218-9

DOI 10.1007/s12185-014-1645-4

The author would like to correct the errors in the publication of the original article. The corrected details are given below for your reading.

\section{References}

1. Yoshida T, Georgopoulos K. Ikaros fingers on lymphocyte differentiation. Int J Hematol. 2014;100:220-9.

2. Yokota T, Kanakura Y. Role of tissue-specific AT-rich DNA sequence-binding proteins in lymphocyte differentiation. Int J Hematol. 2014;100:238-45.

3. Shimazaki N, Lieber MR. Histone methylation and V(D)J recombination. Int J Hematol. 2014;100:230-7.

4. Johanson TM, Skinner JPJ, Kumar A, Zhan Y, Lew AM, Chong MMW. The role of microRNAs in lymphopoiesis. Int J Hematol. 2014;100:246-53.

The online version of the original article can be found under doi: 10.1007/s12185-014-1645-4.

T. Yokota $(\bowtie)$

Department of Hematology and Oncology, Osaka University

Graduate School of Medicine, 2-2 Yamada-oka, Suita,

Osaka 565-0871, Japan

e-mail: yokotat@bldon.med.osaka-u.ac.jp 